\title{
Prevalence of head and neck tumours in Calabar, South Eastern Nigeria
}

\author{
Okezie Obasi Kanu', Martin A Nnoli², Chinyere A Asoegwu' \\ ${ }^{1}$ Department of Surgery, College of Medicine, University of Lagos \& Lagos University Teaching Hospital, Idi-araba, Lagos State, Nigeria, \\ ${ }^{2}$ Department of Anatomic and Forensic Pathology, College of Medicine, University of Calabar, Calabar, Cross-River State, Nigeria
}

Background: Malignancies in the head and neck region though relatively rare, compared to other regions of the body, they contribute significantly to morbidity and mortality in affected patients. In Nigeria, the burden of managing head and Neck malignancies is enormous and there is yet to be a unified record of nation-wide incidence of malignancies involving the head and neck region despite the fact the head and neck malignancies have been diagnosed and documented since the 1960's. The histological pattern and frequency however seems to have some slight variation depending on the region and the identified aetiological risk factors. Aims and Objectives: The aim of this study was to determine the pattern of head and neck tumours seen in the region and the commonest malignancies in the cohort. By comparing the relative prevalence of the lesions with other centers in the country and international published literature we hope to make a case for proper tumour registry and move for nation-wide studies. Materials and Methods: The authors reviewed the histopathological data of the tumor registry at the University of Calabar Teaching Hospital, a major referral Center in South-Eastern Nigeria between 2005 and 2012. All cases of head and Neck tumours with histological diagnosis were included for analysis, their demographic data were obtained and analyzed using SPSSv16. Results: Two hundred and twenty-five specimens from the head and neck region were analyzed during this 6 year period giving an average of 34 cases per year. The Male:Female ratio was 1.2:1. The age range was from 2 years to 76 years with overall mean of 32.7 years. One hundred and forty-five cases $(63.3 \%)$ were benign while 84 malignant cases $(36.7 \%)$ were recorded for the study period. The average number of new malignant cases seen was 14 per year. Malignancies were commoner in those less than 50 years of age and were mostly those of epithelial origin. Conclusion: Variations in the regional demographics of head and neck tumors in the country could be accounted for by the differences in data collection methods and certain aetiological factors that may be unique to those regions. A proper tumor registry in each region, harmonized with a national cancer registry may resolve some of these discrepancies.

Access this article online

Website:

http://nepjol.info/index.php/AJMS

DOI: 10.3126/ajms.v7i3.14216

E-ISSN: 2091-0576

P-ISSN: 2467-9100

Key words: Head and Neck, Malignancies, Carcinoma, Nigeria, Africa

\section{INTRODUCTION}

Head and neck tumours constitute a wide spectrum of heterogeneous tumours affecting different anatomical sites in the head and neck region, with varying histology and biological behaviors.

The different sites include sinonasal, nasopharyngeal, parapharyngeal, oral and oropharyngeal, hypopharyngeal, laryngeal, otologic, orbital, thyroid and parathyroid, and salivary gland tumours. The different subtypes include squamous cell carcinomas, paranasal sinus and nasopharyngeal carcinomas, salivary gland cancers, melanomas, sarcomas, lymphomas and lymphatic tumours, orbital tumours, thyroid and parathyroid gland tumours and other neuroendocrine tumours. ${ }^{1-3}$

Malignancies in the head and neck region though relatively rare, compared to other regions of the body, they contribute significantly to morbidity and mortality in affected patients. ${ }^{4}$ 
Head and neck cancer accounts for $4 \%$ of all new cancer cases and $2 \%$ of all cancer deaths in the United States annually. ${ }^{5}$ The annual worldwide incidence of head and neck canceris approximately 500,000. About 40,000 to 52,000 new cases per year of head andneck cancer are diagnosed in the United States with an estimated 11,000 deathsper year and a male to female ratio of about $2: 1.6$

The rates of head and neck cancers are highest in countries like France, India, Brazil, and USA. But the age-adjusted rates in females are highest among Indians. ${ }^{7-9}$

The grouping and classification of these lesions have equally enjoyed wide variability among many researchers thus making comparism of trends and patterns difficult across geographical boundaries. ${ }^{10,11}$

In Nigeria, the burden of managing head and Neck malignancies is enormous and there is yet to be a unified record of nation-wide incidence of malignancies involving the head and neck region despite the fact the head and neck malignancies have been diagnosed and documented since the 1960's. ${ }^{12}$ Despite the burden of management of these pathologies on the head and neck surgeons and other care givers, the aetiology is still unclear. The histological pattern and frequency however seems to have some slight variation depending on the region and the identified aetiological risk factors. ${ }^{8,13}$

This is a review of the histological pattern of head and neck tumours in Calabar, South Eastern Nigeria.

\section{MATERIALS AND METHODS}

This retrospective study reviewed the histopathologicaldata of a tertiary hospital referral tumor registry between 2005 and 2012. This study was conducted at the University of Calabar Teaching Hospital, a major referral Center in South-Eastern Nigeria. All cases of head and Neck tumours with histological diagnosis were included for analysis of age, sex, primary site and histologic type. Orbital and intracranial malignancies were excluded because of their peculiarities and the fact that such cases were at the period of study, referred outside the center.

Statistical analysis was done using SPSS 16.

\section{RESULTS}

Two hundred and twenty-five specimens from the head and neck region were analyzed during this 6 year period giving an average of 34 cases per year (Table 1). There were
125 (54.6\%) males and 104 (45.4\%) females (M:F ratio of 1.2:1). The age range was from 2 years to 76 years with overall mean of 32.7 years. The estimated mean age was 33 years for males and 32 years for females.

One hundred and forty-five cases (63.3\%) were benign while 84 malignant cases $(36.7 \%)$ were recorded for the study period. The average number of new malignant cases seen was 14 per year. Of the malignant cases, $85.7 \%$ were of epithelial origin, followed by lymphomas (10.7\%) Carcinoma was commoner in those less than 50 years of age and $42 \%$ of these malignant tumors occurred in those less than 30 years of age.

(Figures $1 \& 2$ summarize the gender and age distribution of the tumours respectively).

\begin{tabular}{llcc}
\multicolumn{3}{l}{ Table 1: Basic demographics } \\
\hline Variable & Category & $\begin{array}{c}\text { Frequency } \\
\mathbf{N = 2 2 9}\end{array}$ & $\%$ \\
\hline Gender & Male & 125 & 54.59 \\
Pathology & Female & 104 & 45.41 \\
& Benign & 145 & 63.3 \\
Age & Malignant & & 36.7 \\
& $<20$ & 53 & 23.1 \\
& $20-30$ & 64 & 27.1 \\
& $30-40$ & 39 & 17.0 \\
& $40-50$ & 32 & 14.0 \\
& $50-60$ & 20 & 8.7 \\
& $60-70$ & 13 & 5.7 \\
& $>70$ & 8 & 3.5 \\
\hline
\end{tabular}

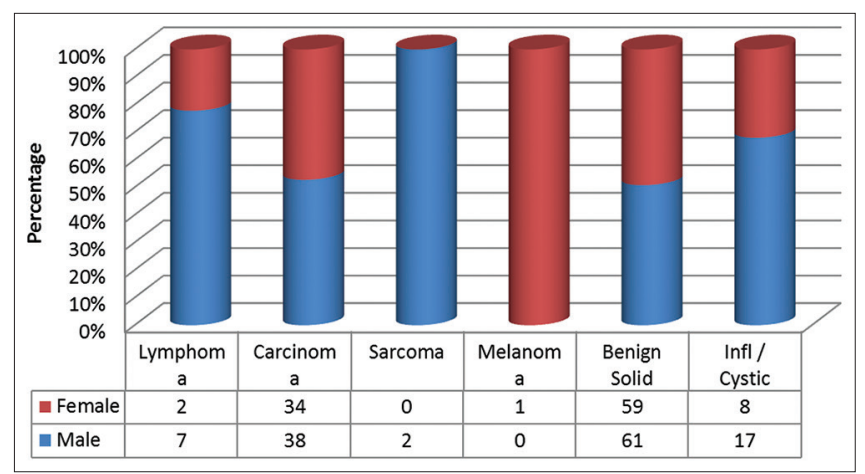

Figure 1: Distribution of lesions according to gender

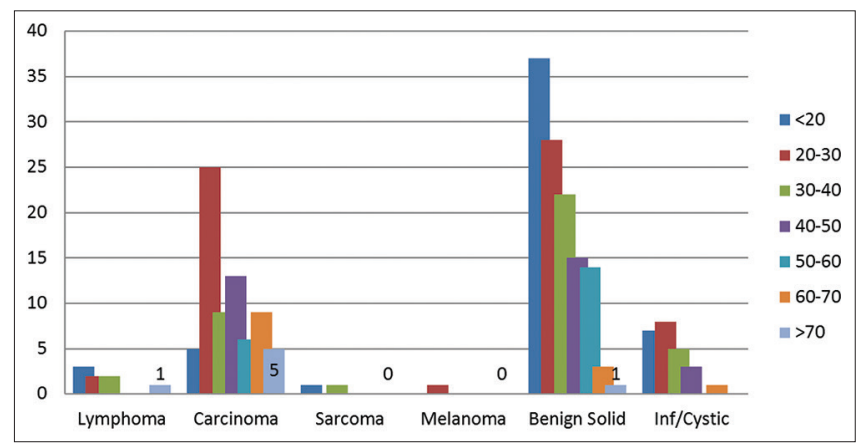

Figure 2: Age distribution of lesions 


\section{DISCUSSION}

A number of reports on head and neck lesions published in Nigeria and Sub-Saharan Africa shows variation in the frequency of the individual lesions seen. Diagnostic reporting and accuracy are affected by the available diagnostic technological tools in the region. Some of these reports focused mainly on malignant tumors but it is established that the commonest malignancy of the head and neck region is Carcinoma. ${ }^{14-17}$ This is the pattern observed all over the world. ${ }^{1,18,19}$ Some local studies by Bhatia $^{20}$ and Amusa et $\mathrm{al}^{21}$ had ranked lymphoma higher than carcinoma but these are exceptions. The current review showed that lymphomas were less common in the region.

The average number of head and neck lesions was 34 per year. The frequency of histologically diagnosed malignancies was 14 per year. This is relatively low compared to studies conducted in other regions of the country. ${ }^{14,16,20-23}$

The male to female ratio in this study 1.2: 1 . This falls within the range of 1.1 to $2.3: 1$ found in most studies around the country. ${ }^{14,16,22,24,25}$

The mean age of presentation for head and Neck lesions in this study was 32.7 years (33years for males and 32 years for females). This is lower than most studies conducted around the world. ${ }^{18,19,26,27}$

Malignancies were found to be higher in those less than 50 years of age in this study and $42 \%$ of the malignancies were found in those below 30 years of age. Otoh et al had reported that a considerable proportion of malignancies in Jos, Nigeria were seen in patients below 30 years of age and attributed this to rising incidence of viral-associated malignancies and immunosuppression. ${ }^{28,29}$ This increasing incidence could also be attributed to increasing awareness and improved healthcare facilities with improved detection rate, now accessible to the patients. ${ }^{26}$ Head and neck cancers in Yemen are commoner in adults 40 to 60 years of age. ${ }^{30}$ This is similar to what obtains in studies in some parts of the country and other countries. ${ }^{17,23,31}$

The variations seen in the regional demographics of head and neck tumors in the country could be accounted for by the differences in data collection methods and certain aetiological factors that may be unique to those regions. A proper tumor registry in each region, harmonized with a national cancer registry may resolve some of these discrepancies. Vital information may have been lost because some patients' information were never recorded and registered.

\section{REFERENCES}

1. Jemal A, Tiwari RC, Murray T, Ghafoor A, Samuels A, Ward E, et al. Cancer statistics, 2004. CA: A Cancer Journal for Clinicians 2004;54(1):8-29.

2. Ragin CC, Modugno $F$ and Gollin SM. The epidemiology and risk factors of head and neck cancer: a focus on human papillomavirus. Journal of dental research 2007;86(2):104-114.

3. Cohen EW, Stenson K, Milano M and Vokes E. Head and Neck Cancer. In: Chang A, Hayes D, Pass H, Stone R, Ganz P, Kinsella T, et al., editors. Oncology: Springer New York; 2006. p. 535-551.

4. Fan CY. Epigenetic alterations in head and neck cancer: prevalence, clinical significance, and implications. Current oncology reports 2004;6(2):152-161.

5. Moyer JS and Bradford CR. Head and Neck Malignancies. Surgery: Springer; 2008. p. 2097-116.

6. Siegel R, Naishadham D and Jemal A. Cancer statistics, 2012. CA: a cancer journal for clinicians. 2012;62(1):10-29.

7. Elango JK, Gangadharan P, Sumithra $S$ and Kuriakose MA. Trends of head and neck cancers in urban and rural India. Asian Pacific journal of cancer prevention: APJCP 2006;7(1):108-112.

8. Sankaranarayanan R, Masuyer E, Swaminathan R, Ferlay J and Whelan S. Head and neck cancer: a global perspective on epidemiology and prognosis. Anticancer research 1998;18(6B):4779-4786.

9. Parkin DM, Pisani P and Ferlay J. Estimates of the worldwide incidence of 25 major cancers in 1990. International journal of cancer 1999;80(6):827-841.

10. Doobaree IU, Landis SH, Linklater KM, El-Hariry I, Moller H and Tyczynski J. Head and neck cancer in South East England between 1995-1999 and 2000-2004: An estimation of incidence and distribution by site, stage and histological type. Oral oncology. 2009;45(9):809-814.

11. McCartan BE, Cowan CG and Healy CM. Regional variations in oral cancer incidence in Ireland. Oral oncology 2005;41(7):677-686.

12. da Lilly-Tariah OB, Somefun $A O$, Adeyemo WL. Current evidence on the burden of head and neck cancers in Nigeria. Head \& neck oncology 2009;1:14.

13. Ernster JA, Sciotto CG, O'Brien MM, Finch JL, Robinson LJ, Willson $\mathrm{T}$, et al. Rising incidence of oropharyngeal cancer and the role of oncogenic human papilloma virus. The Laryngoscope 2007; 117(12):2115-2128.

14. Nwawolo CC, Ajekigbe AT, Oyeneyin JO, Nwankwo KC and Okeowo PA. Pattern of head and neck cancers among Nigerians in Lagos. West African journal of medicine 2001;20(2):111-116.

15. Onyango JF, Awange DO, Njiru A and Macharia IM. Pattern of occurrence of head and neck cancer presenting at Kenyatta National Hospital, Nairobi. East African medical journal 2006;83(5):288-291.

16. Akinmoladun $V$, Pindiga $U$, Akintububo $O$, Kokong $D$ and Akinyamoju C. Head and Neck Malignant Tumors in Gombe, Northeast Nigeria. Journal of the West African College of Surgeons 2013;3(3):1.

17. Adeyemi BF, Adekunle LV, Kolude BM, Akang EE and Lawoyin JO. Head and neck cancer--a clinicopathological study in a tertiary care center. Journal of the National Medical Association 2008;100(6):690-697.

18. Siegel RL, Miller KD and Jemal A. Cancer statistics, 2015. CA: A Cancer Journal for Clinicians 2015;65(1):5-29.

19. Torre LA, Bray F, Siegel RL, Ferlay J, Lortet-Tieulent J, Jemal A. Global cancer statistics, 2012. CA: a cancer journal for clinicians. 2015;65(2):87-108. 
20. Bhatia PL. Head and neck cancer in Plateau state of Nigeria. West African journal of medicine 1990;9(4):304-310.

21. Amusa YB, Olabanji JK, Akinpelu VO, Olateju SO, Agbakwuru EA, Ndukwe N, et al. Pattern of head and neck malignant tumours in a Nigerian teaching hospital--a ten year review. West African journal of medicine 2004;23(4):280-285.

22. Otoh EC, Johnson NW, Danfillo IS, Adeleke OA and Olasoji HA. Primary head and neck cancers in North Eastern Nigeria. West African journal of medicine. 2004;23(4):305-313.

23. Adisa AO, Adeyemi BF, Oluwasola AO, Kolude B, Akang EE and Lawoyin JO. Clinico-pathological profile of head and neck malignancies at University College Hospital, Ibadan, Nigeria. Head and face medicine 2011;7:9.

24. Ologe F, Adeniji K and Segun-Busari S. Clinicopathological study of head and neck cancers in Ilorin, Nigeria. Tropical doctor 2005;35(1):2-4.

25. Iseh K and Malami S. Pattern of Head and Neck Cancer in Sokoto. Nigerian Journal of Otorhinolaryngology 2006;3(2):77-83.

26. Abdulai A, Nuamah I, Avogo D, Gyasi R and Dakora T. Primary malignant head and neck tumours in Ghana: a survey of histopathological charts over two decades. International Journal of Medicine and Biomedical Research 2013;2(1):75-83.

27. Bhurgri $Y$, Bhurgri A, Usman A, Pervez S, Kayani N, Bashir I, et al. Epidemiological review of head and neck cancers in Karachi. Asian Pacific journal of cancer prevention: APJCP 2006;7(2):195-200.

28. Otoh EC, Johnson NW, Ajike SO, Mohammed A, Danfillo IS and Jallo PH. Primary head and neck cancers in North -Western Nigeria. West African journal of medicine 2009;28(4):227-233.

29. Otoh EC, Johnson NW, Mandong BM and Danfillo IS. Primary head and neck cancers in Jos, Nigeria: a re-visit. West African journal of medicine. 2006;25(2):92-100.

30. Abdul-Hamid G, Saeed NM, Al-Kahiry W and Shukry S. Pattern of head and neck cancer in Yemen. The Gulf journal of oncology 2010(7):21-24.

31. Manjari M, Popli R, Paul S, Gupta VP and Kaholon S. Prevalence of oral cavity, pharynx, larynx and nasal cavity malignancies in Amritsar, Punjab. Indian Journal of Otolaryngology and Head and Neck Surgery 1996;48(3):191-195.

Authors Contribution:

OOK - Concept and design of the study, interpretation of data, review of literature, manuscript preparation and critical revision of the manuscript; MAN - Conceptualized study, collected data, statistically analyzed and interpreted data, critical review of manuscript; CAN - Literature search, interpretation of data, preparation of manuscript and critical revision of the manuscript. 